\title{
THE INFLUENCE OF THE SARS-COV2 PANDEMIC ON HOME AND PERSONAL NEEDS BANK LOANS OF THE POPULATION IN ROMANIA IN 2020
}

DOI: https://doi.org/10.18509/GBP210425t

UDC: 336.77:330.567.22]:616.98:578.834\}-036.21(498)"2020"

\author{
Camelia Teodorescu ${ }^{1}$ \\ Iulian Bleotu ${ }^{2}$ \\ Andrei Ducman' \\ Laurentiu-Stefan Szemkovics ${ }^{3}$ \\ Cristian Cazacu ${ }^{1}$ \\ ${ }^{1}$ University of Bucharest, Faculty of Geography, Department of Human and Economic \\ Geography; Bucharest, Romania CAIMT (Research Center for Integrated Analysis and \\ Territorial Management), University of Bucharest, Romania \\ ${ }^{2}$ Master's student in International Relations and Economic Policies EURASIA, \\ Moscow, Russia \\ ${ }^{3}$ National Central Historical Archives, Bucharest, Romania
}

\begin{abstract}
Each period features typical aspects regarding investment in a certain field. Home and personal needs purchases by accessing bank loans have become more and more attractive. Our study analyzes this situation of home and personal needs bank loans accessed by the Romanian population in the first six months, January-July 2020. The analysis is made based on the data given by the National Bank of Romania and the National Fund of Deposit Guarantee from Romania. The methodology relied on tracking the two types of loans, for personal needs and homes and on the graphic representation of their distribution. The distribution map based on the two types of credits in counties, expanded regionally and then nationally for every month (January-July) in 2020 offers the bird's eye view upon this situation. The results of the survey follow firstly the attitude differences of the population in Romania regarding accessing home and personal needs loans before and after the Sars CoV 2 pandemic. The Covid 19 pandemic unpredictably influences many Romanians' budgets and implicitly the whole Romanian economic landscape. In each region from Romania there are counties with a high economic potential which go beyond the national ratio. Equally there are counties where the economic potential is lower. This is exactly the reason why we tried to capture in this survey the situation from each county. The incomes of the population influence accessing bank loans, regardless of their type. Because the statistics data have been issued until mid 2020, the situation is not very highly visible, but there is a shaped tendency concerning the orientation of the population towards a certain type of consumption. We intend to continue the survey for the next months of 2020 after this year as well.
\end{abstract}

Keywords: bank loans, population, pandemic, economy

\section{INTRODUCTION}

The need to purchase consumer goods or economic goods is a need often expressed through spending level or expenses [2]. These expenses may exceed the available budget at some point. In these situations, bank loans are used. Banks welcome and support the 
population by providing loans for personal needs and loans for the purchase of a home. The conditions under which these loans are obtained are not at all similar, but they are often influenced, and at the same time, dependent on the income of those who access bank loans and the possible guarantees that come with their support, depending on the type of loan. Under the conditions that the incomes are diminished after the dismissals, increases of the arrears at the bank rates are automatically registered. Research in this area highlights solutions for staggering or deferring payments [4], [6], [1], [3], [5]. The current situation, that of 2020 is a special one, under the influence of the pandemic with COVID 19. The situation falls into the category of unforeseen events, thus there are difficult times for several categories of employees, especially in services, including tourism [12], [14], [16]. Most of those who have suffered jobs are young people, many of whom are registered as beneficiaries of bank loans [10], [11]. The present study presents a situation of the bank credit management capacity accessed both in the period prior to the pandemic with COVD 19, considered as the degree of indebtedness of the population (fig. 1), as well as during the six months of 2020, but also the arrears registered within this last period, both at the level of Romania and at the level of each geographical region.

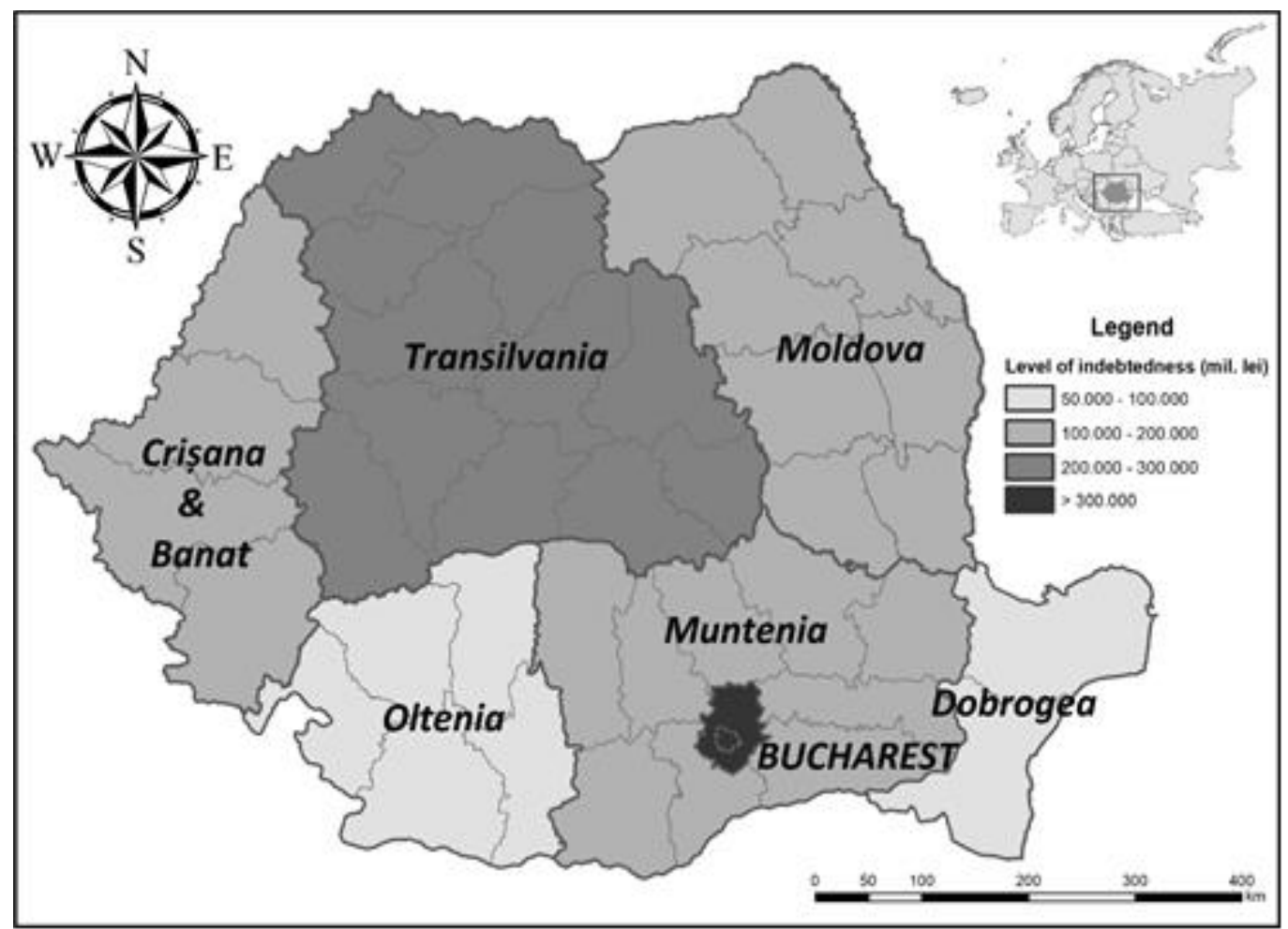

Figure.1. Romania's geographical position in Europe and the degree of bank indebtedness of the population in each province of Romania during January-July 2020

\section{METHODOLOGY}

The entire study is profiled on data provided by the National Bank and the National Bank Deposit Guarantee Fund of Romania (FGDB). Tracking the behavior of the consumer of bank loans highlights various situations. Most follow the pattern of the classic consumer - they pay the installments along with other expenses, considered mandatory, restricting personal expenses. This methodological result is visible when, according to the data provided, the following are analyzed in parallel: the loans accessed and granted, the arrears, the bank deposits made by the population, registered for the same period. 
Regarding loans and arrears, it is necessary to follow, those in lei and those in foreign currency. In this way you can see the trust that those who access loans have in terms of the currency in which they receive their salary or obtain their income.

\section{RESULTS AND DISCUSSION}

The year 2020 was and remains the year of financial challenges. During the first six months of the year, bank loans fluctuated quite a bit in terms of accessing and granting them. The general trend for the six months analyzed is upward for loans in the national currency (fig. 2), which cannot be stated about foreign currency loans accessed by the Romanian population (fig. 3).

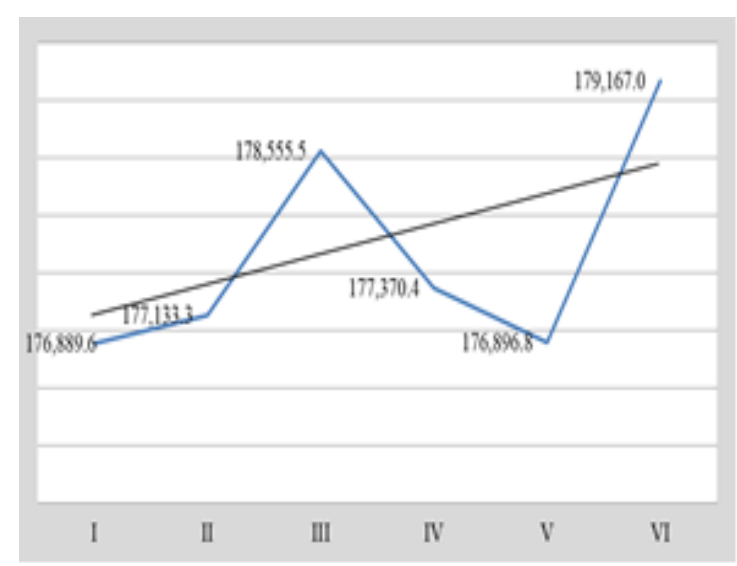

Figure. 2. The evolution of loans in lei from Romania during January-June 2020

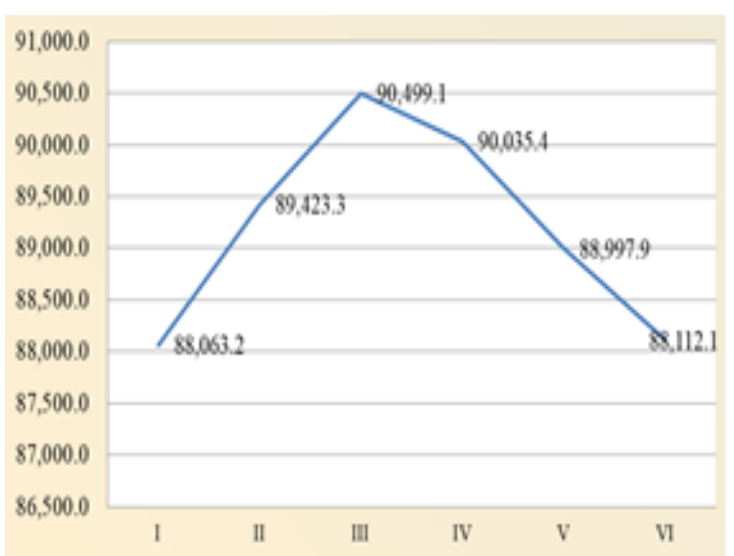

Figure. 3. The evolution of foreign currency loans in Romania during January-June 2020

Careful tracking of absolute values shows fairly large oscillating values. In January and February, including March, that is the pre-pandemic period, access to credit is increasing. Once the pandemic and the imposition of restrictions are triggered, a sharp decrease in these loans can be observed until May. When relaxations are felt and many actually resume work, loan applications appear in May-June.

The two types of loans analyzed for the population of Romania, offer a different image of the preferences and goals that the population proposes. Home loans continue to remain on an upward slope, regardless of its conditions or the risks the year 2020 may offer (fig. 4). Analyzing the situation of these types of loans in the six provinces (Transylvania, Banat-Crisana, Muntenia, Moldova, Dobrogea and Oltenia), we find differences - the value differences are less relevant given the size of each province, but important are the monthly fluctuations from each province (fig. 5). Thus, in the pre-pandemic months, January and February, accessing loans for personal needs is an upward trend phenomenon, in perfect agreement with the income of the population. In these types of loans there are also assimilated the loans for the purchase of cars, excluding the new ones, where the loans are specific.

Also, during this period, the credits for the purchase of vacations corresponding to the warm period of 2020 represent a considerable percentage. The tourism trade enables the acquisition of an attractive offer in terms of value, influencing the behavior of the tourism consumer. Once the SARS CoV2 epidemic is triggered, the population's behavior changes, therefore there appears a downward slope between March and May, more precisely in the period when quarantine is imposed. Loans for personal needs are accessed during this period as well, but reduced in terms of value, oriented towards goods that 
support the development of economic activity from home or home-work. These are mainly computers and electronic equipment.

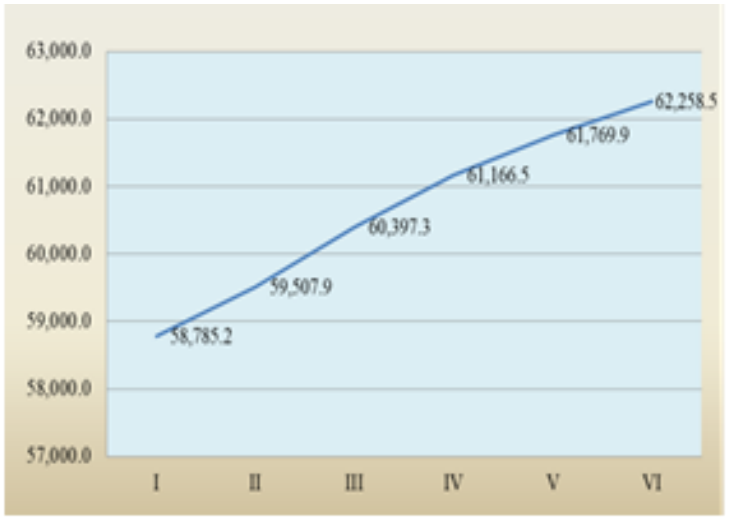

Figure. 4. Romania home loans in lei during January-June 2020

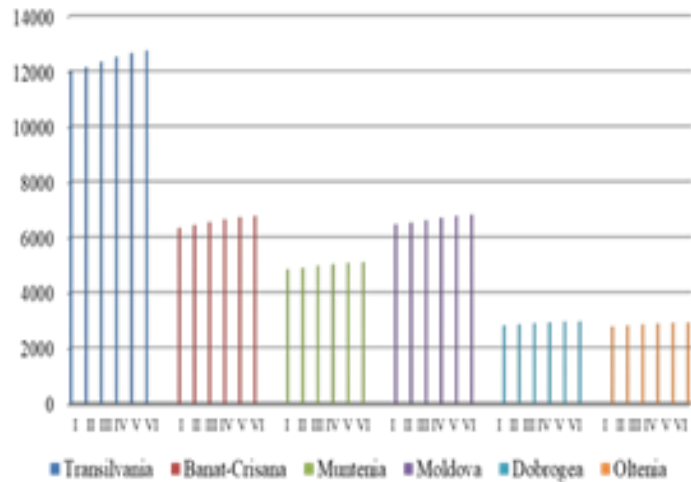

Figure. 5. Loans in lei for housing in each province of Romania during January-June 2020

Regarding the loans for personal needs, the behavior of the Romanian population is different from one month to another, for the period under analysis - January-July 2020 (fig. 6 and fig. 7).

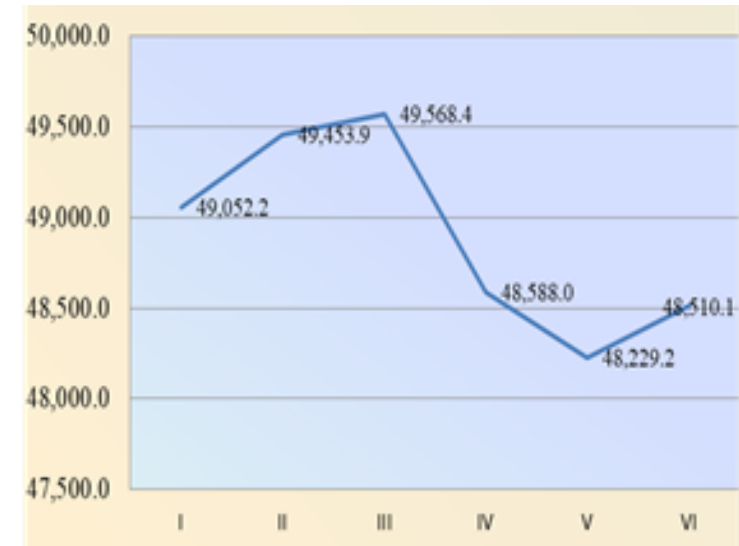

Figure 6. Consumer loans in lei in Romania during January-June 2020

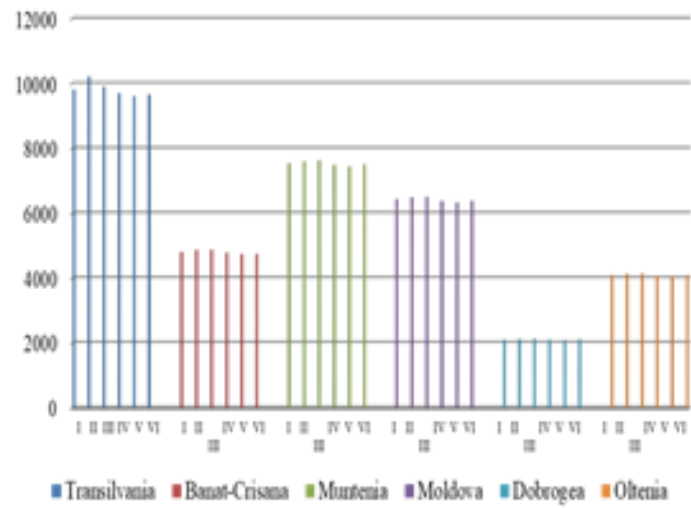

Figure 7. Loans for consumption in lei in each province of Romania during January-June 2020

The unforeseen situation triggered by the pandemic of COVID 19, also brings upset in terms of repayment of installments on loans accessed in previous periods, many of them having a fairly long history. This situation is amplified by several elements: the inherent arrears or arrears that may occur regardless of the economic situation; arrears arising from misunderstandings triggered by the authorities' messages regarding the deferral of installments for those who have bank loans; another reason is the poor communication between banks and the population regarding the postponement of bank installments in the situation given by the COVID 19 pandemic; last but not least, the arrears appeared as a result of the reduction of incomes - technical unemployment or of dismissals, the incomes of the population becoming incapable to cover the bank installments (fig. 8 and fig. 9). The worst financial situations are registered by HoReCa companies, at least in the first period of the pandemic crisis. It is then easily possible to register a potential to adapt to the given conditions. The employees had a lot to suffer, as their incomes decreased continually one month to another. These declines also have effects upon bank loans, 
accessed mostly in the years or months just before the pandemic. Loan arrears are recorded in both the national currency (leu) or the international currency.

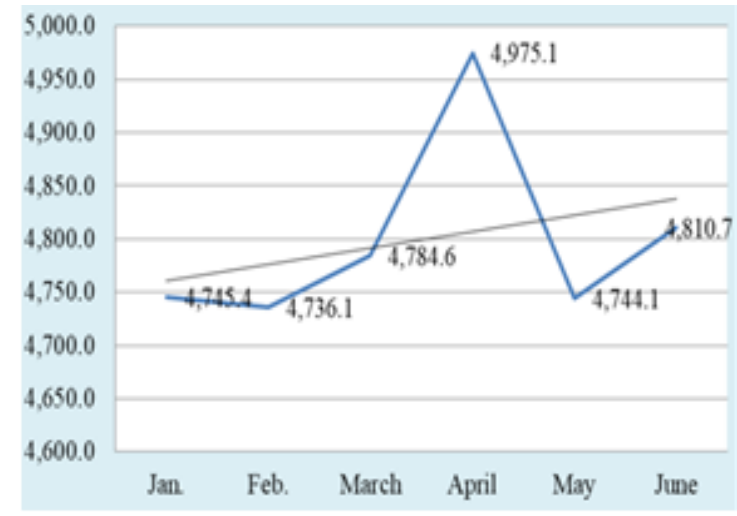

Figure 8. The evolution of overdue loans in lei in Romania during January-June 2020

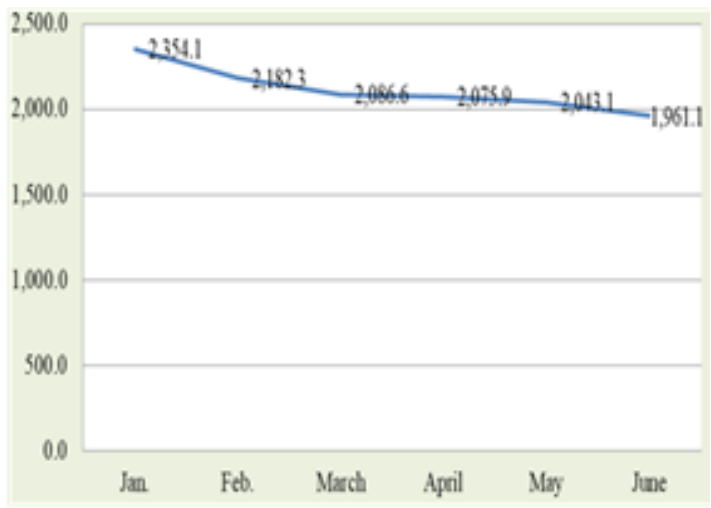

Figure 9. Evolution of arrears on foreign currency loans in Romania during January-June 2020

Adapting the economic activities to this special situation has become a priority for most entrepreneurs. Among them, there range those functioning in the tourist field, owners of accommodation structures, especially pensions/ hostels or small hotels. Many of the guesthouses have had the ability to adapt more easily to the imposed conditions, especially those related to social distance, the movement of people inside and outside them, the endowment with high speed internet for those who worked in this way. Most of these accommodation structures offered suitable working conditions for those who needed relaxation after school hours, through special recreational activities (the natural setting being the one that majorly contributed to this situation), hiking being the most attractive and recommended one during this period. To these ones, there are also added other activities, such as workshops, in which children are trained mainly. These workshops can also be used for educational purposes. They involve a small number of people and can have beneficial effects on the acquired knowledge regarding certain fields, crafts but also cultural values of some ethnic groups [13], [14]. Other areas where economic activities in the field of services have been registered, including agri-tourism accommodation areas, have been registered in the vicinity of important natural resources such as salt deposits or special natural phenomena [12], [15], [9]. What stood out during this period, was the ability to adapt the economic activity of each economic unit, regardless of the specifics, to the given conditions. A resilient, sustainable economy is an economy that has the ability to adapt to special conditions, and this period is one of them [7], [8].

Another registered phenomenon was the return to Romania of a fairly high number of people who worked outside Romania's borders, especially in the European Union. The effects of this phenomenon were both positive and negative. The positive effect could be noticed by recording and evaluating the bank deposits (fig. 10). Despite the declining income of the Romanian population in January-July 2020, bank deposits registered a slight increase. This phenomenon can be explained both by the participation in the creation of these deposits of the middle-income population, but also of those who obtained a higher profit working abroad. This financial-banking phenomenon is registered in all regions of Romania and can be considered as a positive thing.

The negative effects registered with the return to Romania of those who left for the countries of the European Union, were related to the lack of occupation and, implicitly, 
of incomes. For many of them, their income was a source of consumption, but limited to a certain duration. Most Romanians who returned from the European Union countries were from all counties, without noticing certain regions.

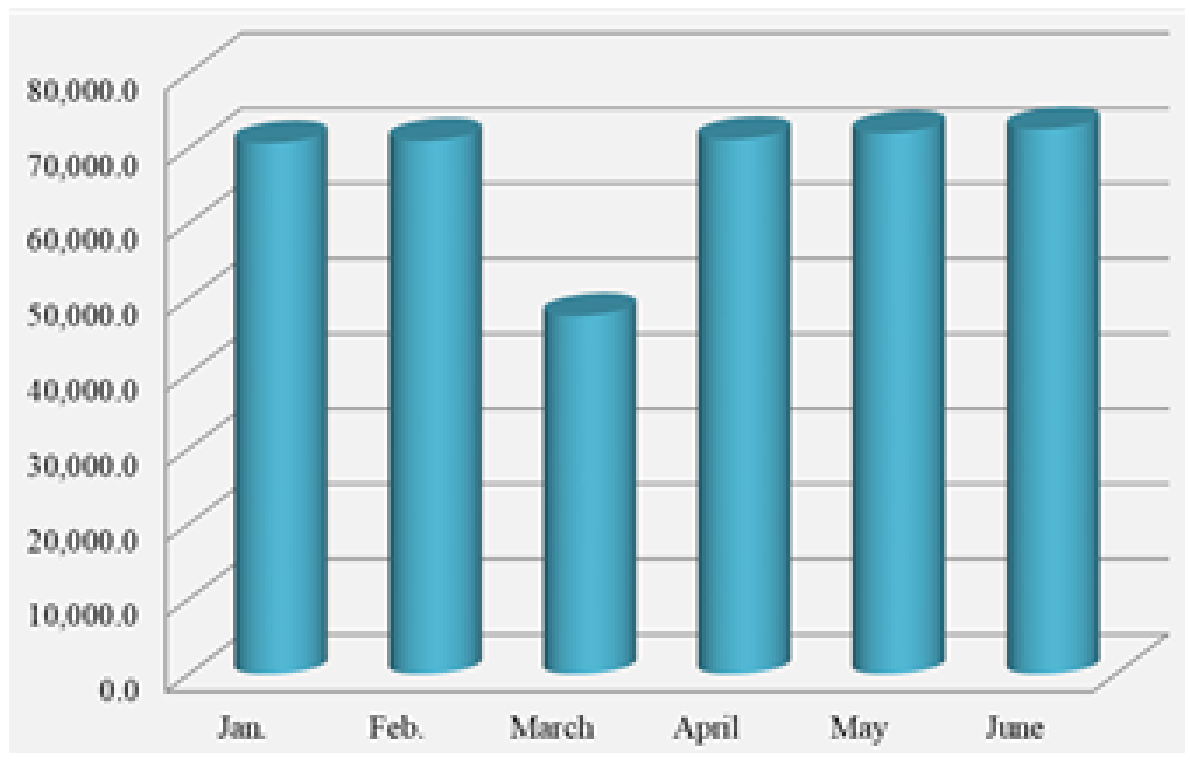

Figure 10. The evolution of bank deposits in lei of the Romanian population during January-June 2020

\section{CONCLUSIONS}

The economic situation that Romania is going through is not a unitary one, but it is one registered at a worldwide level. Adapting the economy to special situations is a necessity. The evaluation of the national economy highlights areas that have a significant increase in turnover, in the pay related to wages and expansion in work networks. On the other hand, there are areas that have restricted their work capacity until its final cessation. The areas in Romania that had the capacity to adapt economically can also be noticed through bank indicators, such as bank loans and deposits, regardless of currency (national or international). Equally notable there are the areas that have a higher inertia in terms of adaptability, using the same banking indicators. Among the provinces, it stands out in terms of accessing and obtaining loans for housing in Transylvania, whose trend is upward, throughout the analyzed period. The ascendant situation is common in all regions of Romania, but here the slope is much more accentuated. The capital, Bucharest, is positioned in a similar situation. The oscillations it registers regarding loans for personal needs are clearly expressed in all regions of Romania in March, the month in which the COVID 19 pandemic is established. It is a natural reaction of the population to an unprecedented situation. The simple form of financial protection was expressed by population by reducing expenses, especially those with a credit card, or accessing consumer loans or personal need loans. Starting with May, relaxation is also felt among consumers. In this way, we can say that an economic adaptation at individual level is necessary.

Everyone must have the ability to understand that the transformations that the world economy is going through, bring permanent changes. In this case, obtaining income is possible only by adapting our educational and working capacity. This principle must be respected, and the economy of each state, including Romania, will find those solutions for economic recovery. 


\section{REFERENCES}

[1] Burlacu Sorin, Cãtãlin-Razvan Dobrea, Dumitru-Alexandru Bodislav \& Cristina Dima, Structural Changes In The Romanian Economy-Opportunities For New Workplaces, Proceedings of the International Management Conference, Bucharest, Romania, vol. 13, issue 1, pp. 11301141,2019

[2] Dinu Felicia Alina \& Razvan Catalin Dobrea, Corporate SRI and Financial Performance: A Panel Data Analysis, Journal of Applied Management and Investments, Department of Business Administration and Corporate Security, International Humanitarian University, vol. 2, issue 3, pp. 168-175, 2013

[3] Dobrea Razvan Catalin \& Iulia Xenia Podgoreanu, The Romanian Competitiveness Crisis In The European Context: A Comparative Approach At The Central And East European Level, Proceedings of the International Management Conference, Bucharest, Romania, vol.7, issue 1, pp. 641-650, 2013

[4] Dragomir Gh. \& Tomita I., Productivitatea muncii, Editura Universitaria, Craiova, Romania, 1997

[5] Mihaela Gadoiu, Advantages and limitations of the financial ratios used in the financial diagnosis of the enterprise, Scientific Bulletin-Economic Sciences, University of Pitesti, Romania, vol. 12, issue 2, pp. 87-95, 2014

[6] Gadoiu Mihaela, The Optimization Of The Enterprise Financial Analysis Trough The Financial System Of Control Du Pont, Annals-Economy Series, Constantin Brancusi University, Faculty of Economics, Pitesti, Romania, vol. 3, pp. 236-240, 2016

[7] Gadoiu Mihaela, Camelia Teodorescu, Daniel Peptenatu, Catalin Dobrea \& Diaconu, Daniel Constantin, The optimization of the local resources in the attenuation of the economic effects given by the mobility of the population in the Danube Port Towns in Romania, 5th International Multidisciplinary Scientific Conferences on Social Sciences and Arts SGEM, Bulgaria,vol. 5, nr. 4.1, pp. 101-108, 2018

[8] Grecu Alexandra, Andreea Karina Gruia, Marian Marin, Mariana Bănuță, Cosmin Olteanu, Ionuț Constantin, Mihaela Gadoiu, Camelia Teodorescu, Răzvan Cătălin Dobrea \& Cristian Constantin Drăghici, Specificity of sustainable structural dynamics of local economy in romanian tourist resorts, Sustainability, vol. 11, Issue. 24, pp. 7155 - 7167, 2019.

[9] Grecu Alexandra, Marian Marin, Camelia Teodorescu \& Cristian Constantin Drăghici, dynamics of the entrepreneurial sector in territorial systems with tourist functionality-structural trends and changes, Annals of Valahia University of Targoviste, Geographical Series, Romania, vol. 18, nr. 2, pp. 144-152, 2018

[10] Matei Elena, Liliana Dumitrache \& Mariana Nae, Iuliana Vijulie \& Anda Nicoleta Onetiu, Evaluating sustainability of urban development of the small towns in Romania, International Multidisciplinary Scientific GeoConference: SGEM, Bulgaria, vol. 3, pp. 1065, 2011

[11] Paliu L., Eficienta economica, Editura Spirit Românesc, Bucuresti, Romania, 1999

[12] Rădoi Irina-Valentina, Andrei Ducman, Camelia Teodorescu, Marian Marin \& Alexandru Gogioiu, The impact of the development of the local economy on the natural environment of the Danube Delta, Romania, Proceedings, Public recreation and landscape protection, Krtiny, Czech Republic 2020, pp. 489

[13] Teodorescu Camelia \& Laurentiu Stefan Szemkovics, The ethno-creativity in the pilot centers in Romania and their role in the development of cultural tourism and the educational process, Forum geografic Geographical studies and environment protection research, Craiova, Romania, vol. 16, nr. 1, pp. 88-97, 2017 
[14] Teodorescu Camelia, Daniel Diaconu \& Roxana Radu, Disfunctionalities in the organization and development of spa tourism developed on salt resources in Maramures, Romania, Public Recreation and Landscape Protection, Czech Republic, vol. 1, nr. 1, pp. 101-105, 2019

[15] Teodorescu Camelia, Laurentiu Stefan Szemkovics, Maria Postea, Andrei Ducman \& IrinaValentina Radoi, Mud volcanoes from Paclele mari, Romania - natural touristic economic resource and environmental value education source, Proceedings, Public recreation and landscape protection, Krtiny, Czech Republic, pp. 305, 2020

[16] Toma Sorin George, Social responsibility and corporate citizenship in the 21th century, The Amfiteatru Economic Journal, Academy of Economic Studies, Bucharest, Romania, vol. 10, issue 23, pp. 80-85, 2008 